\title{
Review Article \\ Increased Oxidative Stress as a Selective Anticancer Therapy
}

\author{
Jiahui Liu and Zhichong Wang \\ State Key Laboratory of Ophthalmology, Zhongshan Ophthalmic Center, Sun Yat-sen University, 54 Xian Lie Nan Road, \\ Guangzhou 510060, China \\ Correspondence should be addressed to Zhichong Wang; wzc001@hotmail.com
}

Received 30 September 2014; Accepted 11 February 2015

Academic Editor: Elisa Giannoni

Copyright (C) 2015 J. Liu and Z. Wang. This is an open access article distributed under the Creative Commons Attribution License, which permits unrestricted use, distribution, and reproduction in any medium, provided the original work is properly cited.

Reactive oxygen species (ROS) are closely related to tumorgenesis. Under hypoxic environment, increased levels of ROS induce the expression of hypoxia inducible factors (HIFs) in cancer stem cells (CSCs), resulting in the promotion of the upregulation of CSC markers, and the reduction of intracellular ROS level, thus facilitating CSCs survival and proliferation. Although the ROS level is regulated by powerful antioxidant defense mechanisms in cancer cells, it is observed to remain higher than that in normal cells. Cancer cells may be more sensitive than normal cells to the accumulation of ROS; consequently, it is supposed that increased oxidative stress by exogenous ROS generation therapy has an effect on selectively killing cancer cells without affecting normal cells. This paper reviews the mechanisms of redox regulation in CSCs and the pivotal role of ROS in anticancer treatment.

\section{Introduction}

Reactive oxygen species (ROS) is a collective term for oxygencontaining chemical species that are converted directly or indirectly from free oxygen but are more chemically reactive [1]. Low to moderate levels of ROS are indispensable to normal cellular proliferation, differentiation, and survival [2]. Some reports have shown that the addition of low concentrations of superoxide or hydrogen peroxide $(10 \mathrm{Nm}-$ $1 \mu \mathrm{M})$ to the culture medium is effective for stimulating the growth of hamster and rat fibroblasts in vitro $[3,4]$. In general, systems in aerobic organisms are developed to modulate the content of ROS by balancing the generation and scavenging of ROS within a nontoxic range. But once the balance is broken, cells suffer from oxidative stress. Rapid increases in intracellular ROS may lead to cellular transformation and tumorigenesis. For example, researchers have found in BHK21 cells that deaths of apoptotic cells become obvious after the exposure to $10-100 \mu \mathrm{M}$ hydrogen peroxide [5]. Substantial growth of ROS brings cells irreversible damage and finally kills them. However, it is just these biological features of ROS that make it possible to be used to kill tumor cells [2].

Since Lapidot discovered leukemia stem cells in 1994, researchers have shed light on the study of cancer stem cells
(CSCs) [6]. CSCs are defined by their capacity to self-renew and differentiate into heterogeneous nontumorigenic cancer cell types in accordance with their microenvironment and the status of the whole body $[7,8]$. CSCs, which only account for about $0.05 \%-1 \%$ of the whole tumor cell population [9-11], play an important role to tumor formation and development. They are believed to relate closely to chemo- and radioresistance and disease recurrence [12-16]. Therefore, CSCs are considered as good targets for cancer therapy [17]. The study of intracellular ROS in CSCs remains an attractive field for research. Little is known about the biological effects and regulatory mechanism of ROS in the CSC subpopulation. This review focuses on ROS's regulation effect on CSCs and the therapeutic effect on cancer eradication.

\section{Lower ROS Production in CSCs}

ROS are mainly composed of free radicals such as superoxide $\left(\mathrm{O}_{2}{ }^{-}\right)$, hydrogen peroxide $\left(\mathrm{H}_{2} \mathrm{O}_{2}\right)$, and hydroxyl radical $\left(\mathrm{HO}^{\circ}\right)$, which contain oxygen and peroxides tending to form radicals [1]. Under physiological conditions, $\mathrm{O}_{2}{ }^{-}$is principally generated as a consequence of incidental electron leakage from the mitochondrial electron transport 
chain (ETC) [18] and is usually immediately converted into $\mathrm{H}_{2} \mathrm{O}_{2}$ by mitochondrial Mn-containing superoxide dismutase (MnSOD, SOD2), cytosolic Cu/Zn-containing SOD1, or extracellular SOD3 $[19,20] . \mathrm{H}_{2} \mathrm{O}_{2}$ can be catalyzed to release highly toxic $\mathrm{HO}^{\circ}$ by gaining an extra electron or be scavenged by the reaction of glutathione peroxiredoxin (Prx), peroxidase (Gpx), or catalase [21-23]. Besides the mitochondrial mechanism, ROS can also be generated by the NADPH oxidase complex (NOX), cyclooxygenase (COX), cytochrome c oxidase, and xanthine oxidase (XO) [24].

The production of cellular ROS must go with scavenging of ROS. The currently available body of evidence shows that powerful scavenger systems, which are mainly divided into two classe: antioxidant enzyme system and sulfur reduction buffer system, can maintain the intracellular ROS at low levels. The former class contains the superoxide dismutase family (SOD1, SOD2, and SOD3), catalase (CAT), and peroxidase. In addition, ascorbic acid and vitamin $\mathrm{E}$ are also involved and play vital roles in antioxidant enzyme system [25]. The latter class contains reduced glutathione (GSH), thioredoxin (TRX), and thioredoxin reductase (TRXR). Glutathione peroxidase converts $\mathrm{H}_{2} \mathrm{O}_{2}$ to $\mathrm{H}_{2} \mathrm{O}$ and $\mathrm{O}_{2}$ through coupling with the transformation of GSH to oxidized glutathione [2]. In general, GSH and GSSG maintain homeostasis within cells, and their contents have become important indicators of the antioxidant capacity of cells [26].

Cells maintain redox homeostasis, which is favorable for organisms, through a balance of generation and elimination of ROS. Aerobic organisms actively use ROS in signal transduction pathways to regulate cell proliferation, differentiation, and survival, in a way of interacting with macromolecules by reversible oxidative modifications [2730], while excessive amounts of ROS, regardless of their source, cause irreversible peroxidation of nucleic acids, lipids, amino acids, and carbohydrates, resulting in cellular senescence, apoptosis, or transformation and triggering a series of pathological processes, such as cardiovascular diseases, neurodegenerative diseases, aging, and cancer [31-36]. For example, ROS induce nuclear DNA mutations by activating oncogene or inactivating tumor suppressor genes and damage nuclear DNA repair mechanisms, resulting in the generation of tumor-initiating cells. Persistent ROS-induced oxidative stress expands the clonal selection of these cells, gradually making them form subsets with new features. Tumor then occurs as a consequence of reduced apoptosis and increased genomic instability and heteromorphism $[37,38]$.

Compared to differentiated cells, normal stem cells are more glycolytic to reduce more oxidative damage due to ROS [39-41]. Similarly, CSCs present lower energy metabolism rate and produce less ROS compared with non-CSCs [17, 42]. This can be achieved by a combination of mechanisms that is unique to a given tumor, such as (a) upregulation of ROS scavengers, (b) downregulation of ROS-producing enzymes, (c) promotion of glycolysis, (d) reduced mitochondrial mass, and (e) low oxygen consumption [43-46]. As evidenced by Ishimoto et al.s study, the CSCs of human gastrointestinal tract improve abilities of GSH synthesis with a cystineglutamate exchange transporter in order to enhance its defensive performance against ROS [47].

\section{ROS Activates HIFs in CSCs}

The morphology, metabolism, and proliferation of CSCs are critically dependent on their microenvironment. CSCs will not only strive for adapting to their microenvironment but also actively create their preferable niche. Hypoxia is an essential feature of the tumor microenvironment because of the chaotic vasculature and poor oxygen diffusion in solid cancers. The normal oxygen tension in healthy tissue is approximately $7 \%(53 \mathrm{mmHg})$, but this tension can show differences in tumors depending on the level of hypoxia, that is, from physiological $(\sim 7 \%)$ to severe $(<1 \%)$ hypoxia [48]. It has become increasingly clear that a hypoxic microenvironment is beneficial for the maintenance of CSCs in virtually all tissues of the body [49-51]. For example, in glioblastomas, hypoxia sustains the undifferentiated state of CSCs by elevating some important stem cell markers, such as Oct4 and Sox2, slows down their growth to the quiescent stage, and increases their colony-forming efficiency and migration [52]. Besides, since hypoxia potentiates the CSCmediated inhibition of $\mathrm{T}$ cell proliferation and activation in glioma and further inhibits macrophage phagocytosis compared with normoxia conditions, immunosuppression can be reinforced [53]. Hypoxia also improves CSCs' abilities of invasion and resistance against therapy, which poses a challenge to anticancer therapeutics [54].

In hypoxic environment, elevated ROS can activate hypoxia inducible factors (HIFs) [48]. HIFs are a type of heterodimers made up from HIF- $1 \alpha$, HIF- $2 \alpha$, or HIF- $3 \alpha$ bound to HIF- $\beta$ /ARNT (aryl hydrocarbon receptor nuclear translocator). While HIF- $\beta$ is constitutively and ubiquitously expressed among many cell types, all HIF- $\alpha$ subunits are regulated by intracellular oxygen sensors, which are referred to as prolyl hydroxylate enzymes and asparaginyl hydroxylase [55]. Under normoxic conditions, the von Hippel-Lindau (VHL) E3 ligase complex targets HIF- $\alpha$ subunits for proteasomal degradation [56]. Under decreased oxygen level, HIF- $\alpha$ subunits can be stabilized through the activation of intracellular signaling pathways by ROS. Take two simple examples. Activation of the PI3K-AKT-mTOR pathway can promote the synthesis of HIF- $\alpha$, while inhibition of hydroxylase activity can prevent HIF- $\alpha$ degradation [55, 57, 58]. A wealth of evidence illustrate that HIFs induce metabolic reprogramming from oxidative phosphorylation to anaerobic glycolysis as well as lactic acid fermentation, by activating lactate dehydrogenase $\mathrm{A}$ and phosphorylating the E1 $\alpha$ subunit of pyruvate dehydrogenase. This metabolic reprogramming is widely accepted as a hallmark of cancer because it can not only earn more ATP for cancer cells but also reduce the cytotoxic ROS levels in order to resolve the energy crisis within vigorous tumors and to help cancer cells survive the state of hypoxia. Additionally, it also enhances resistance to chemotherapy and radiotherapy treatments [59, $60]$. HIF- $2 \alpha$ promotes the expression of multiple antioxidant enzymes and DNA damage repair enzymes, thereby reducing the intracellular ROS levels and limiting the accumulation of DNA damage [61-63]. Only under hypoxia (1\%) can HIF- $1 \alpha$ be stabilized, and a low activity is observed at $5 \%$ $\mathrm{O}_{2}$ (resembling the end-capillary oxygen conditions) [64]. 
However, HIF- $2 \alpha$ is stabilized at a wider range of oxygen tensions, ranging from severe hypoxia ( $<1 \%$ oxygen) to more physiologically relevant tension in tumors $(2-5 \%$ oxygen) $[64,65]$. HIF- $1 \alpha$ and HIF- $2 \alpha$ are highly homologous and bind to similar hypoxic response elements [56]. However, due to their unique target genes and expression patterns, they have their individual biological roles. Li et al. found that, under severe hypoxic conditions, HIF- $2 \alpha$ is markedly expressed only in glioma stem cells but not in nonstem cells, whereas HIF- $1 \alpha$ exists in both tumor subpopulations. It has also been suggested that the HIF- $2 \alpha$-mediated upregulation of Oct4, Glut1, SerpinB9, and VEGF may facilitate CSCs in metabolism, proliferation, survival, and escape from immune surveillance [65]. As evidenced in a number of various tumors in recent studies, hypoxia initially induces a transient activation of HIF- $1 \alpha$ followed by persistent HIF$2 \alpha$ expression occurring after more prolonged periods of hypoxia and this hypoxic switch to HIF- $2 \alpha$ can enhance the CSC population [66-68]. The expression of HIF is associated with the poor survival of patients with cancer [69].

Early CSC model proposed that CSCs are the driving force of tumorigenesis due to their abilities of self-renewal and irreversible multilineage differentiation through either asymmetric or symmetric cell division. In comparison, their offspring, namely, progenitor cells and differentiated cancer cells, no longer possess tumorigenic potential [70]. Therefore, anticancer treatment targeting CSCs holds great promise [24]. However, recently emerging lines of evidence have revised the earlier model to a dynamic model. It is now suggested that CSCs and non-CSCs can be bidirectional converged, an effect that is governed by their microenvironment; that is, progenitor cells and differentiated cells can reacquire their self-renewal capacity through reprogramming into CSCs [12, 71-75]. HIFs are considered as crucial regulators of the stem cell phenotype through Notch signaling pathways and induce the expression of stem cell markers, such as Oct4 [65], and induce pluripotent stem cell (iPSC) factors, Oct4, Nanog, Sox2, Klf4, and c-Myc, in many cancer cell types, including prostate, brain, kidney, cervix, lung, colon, liver, and breast tumors [76]. Similarly, multiple types of CSC-specific cell-surface markers, including CD133, CD44, and VEGF-A, can be markedly upregulated by HIFs [7779], modulating the self-renew potential of CSCs. Studies by Heddleston et al. have elucidated that HIF- $2 \alpha$ can reprogram the nonstem population of gliomas into CSCs through the upregulation of important stem cell factors, such as Oct4, Nanog, and c-Myc [80]. Consequently, it is necessary to evolve current cancer treatments to target both bulk differentiated cells and CSCs in tumor.

\section{Regulation of ROS through CSC Markers in CSCs}

CSCs can be identified and isolated primarily by CSC-specific cell-surface marker expression (Table 1). It has been demonstrated that CD34, CD133, CD44, and ALDH1 mark CSCs in leukemia and some solid tumors [81-86]. Nonetheless, there is a lack of a universal expression of surface markers to identify CSCs in all types of tumors [17]. As mentioned above, ROS-induced HIFs can enhance the expression of a variety of CSC biomarkers. For instance, insulin-like growth factor binding protein 3 (IGBP3) can suppress ROSmediated cytotoxicity by novel insulin-like growth factor (IGF), independent antioxidant activity, thereby increasing $\mathrm{CD} 44 \mathrm{H}$ cells in esophageal squamous cell carcinoma (ESCC) and facilitating ESCC cell adaptation and survival under hypoxia [87]. Interestingly, the biomarkers can modulate the level of ROS via different mechanisms.

It is well known that CD13, which is a marker of liver CSCs, is associated with tumor invasion, angiogenesis, and antiapoptosis $[88,89]$. CD13 is a negative ROS regulator that results in the inhibition of apoptosis and the enhancement of the stemness of CSCs [24]. As a consequence, the survival of liver $\mathrm{CD}_{13}{ }^{+} \mathrm{CSC}$ in hypoxic lesions after chemotherapy contributes to the high expression of aminopeptidase $\mathrm{N}$, a ROS scavenger enzyme. In addition, immunohistochemical analyses have indicated that $\mathrm{CD} 13$ coexists with $\mathrm{N}$-cadherin in surviving cancer cells [89]. Gclm, which encodes a glutamate-cysteine ligase that catalyzes the rate-limiting step in the synthesis of $\mathrm{GSH}$, is overexpressed in the $\mathrm{CD} 13^{+} \mathrm{CD} 90^{-}$ fraction in PLC/PRF/5 cells, the ROS level of which is lower than that of the $\mathrm{CD} 13^{-}$population. Both the CD13neutralizing antibody and $\mathrm{CD} 13$ inhibitor ubenimex can stimulate ROS production, increasing the ROS concentration to that found in $\mathrm{CD}_{13}{ }^{-}$cells. In mouse xenograft models, the administration of ubenimex attenuates the self-renewal and tumor-initiation potentials of $\mathrm{CD}^{+} 3^{+}$cells [90]. Therefore, CD13-neutralizing antibody or other inhibitors can kill CSCs effectively.

As a cellular adhesion molecule for hyaluronic acid, CD44 is the most prevalent CSC molecular marker [91-93] and is widely expressed in multiple tumors, including breast cancer [94], head and neck squamous cell carcinoma [95], pancreatic cancer [96], colorectal cancer [97], and prostate cancer [83]. Its variant isoform, CD44v, can interact with and stabilizes $\mathrm{xCT}$, a subunit of a glutamate-cystine exchange transporter located at the plasma membrane, thereby promoting cystine uptake for GSH synthesis and contributing to ROS defense $[83,97]$, and this finding was validated by the study conducted by Ishimoto et al. on gastrointestinal CSCs [47]. These researchers recently forced the expression of miRNA-328 in gastrointestinal cancer cell lines and found that CD44 expression was reduced, resulting in the repression of cancer cell growth in vitro and in vivo, and impaired resistance to ROS [98]. CD44 thus maintains a key role in the GSH-dependent antioxidant system in cancer cells [99].

CD138, which is also called syndecan-1, belongs to the mammalian syndecan family of heparin sulfate proteoglycans. Shimada et al. obtained holoclones harboring the biological properties of stemness from single-cell cultures of the PC3 human prostate cancer cell lines. Syndecan1 is overexpressed in these holoclones and downregulates the expression of NADPH oxidase, thereby decreasing ROS generation. The in vitro silencing of syndecan-1 strongly destabilizes the holoclones by increasing ROS production, whereas in vivo syndecan-1 deficiency lowers the frequency of primitive cells expressing stem cell markers and markedly 
TABLE 1: Surface markers of cancer stem cells in different types of tumors.

\begin{tabular}{|c|c|c|}
\hline Tumor type & CSC markers & References \\
\hline AML & $\mathrm{CD}_{3} 4^{+} / \mathrm{CD} 38^{-}, \mathrm{CD} 44^{+}, \mathrm{CD} 34^{+} / \mathrm{CD} 123^{+}, \mathrm{CD} 47^{+}$ & {$[6,100-104]$} \\
\hline ALL & $\mathrm{CD} 4^{+} / \mathrm{CD} 10^{-}, \mathrm{CD} 34^{+} / \mathrm{CD} 19^{-}$ & {$[105]$} \\
\hline Bladder cancer & $\mathrm{EMA}^{-} / \mathrm{CD} 44 \mathrm{v} 6^{+}, 67 \mathrm{LR}^{+} / \mathrm{CD} 66 \mathrm{c}^{-}, \mathrm{CD} 44^{+} / \mathrm{CK}^{5+} / \mathrm{CK} 20^{-}$ & {$[106-108]$} \\
\hline Breast cancer & $\begin{array}{l}\mathrm{Lin}^{-} / \mathrm{CD} 44^{+} / \mathrm{CD}^{2} 4^{-/ \text {low }} / \mathrm{ESA}^{+}, \mathrm{ALDH}^{\text {high }}, \mathrm{CD}^{\text {high }}{ }^{\text {hi }} \\
\mathrm{CD} 44^{+} / \mathrm{CD} 49 \mathrm{f}^{\text {high }} / \mathrm{CD} 133 / 2^{\text {high }}, \mathrm{CD}_{176^{+}}\end{array}$ & {$[94,109-112]$} \\
\hline Cervical cancer & $\mathrm{CD} 44^{\text {high }} / \mathrm{CD} 24^{\text {low }}, \mathrm{CD} 49 \mathrm{f}^{+} / \mathrm{CD} 133^{\text {low }}$ & {$[113,114]$} \\
\hline Colorectal cancer & $\begin{array}{l}\mathrm{CD} 133^{+}, \mathrm{CD} 44^{+} / \mathrm{EpCAM}^{+}, \mathrm{CD} 44^{+} / \mathrm{CD}_{166^{+}}, \\
\mathrm{CD}^{+} 4^{+} / \mathrm{CD} 29^{+}, \mathrm{ALDH1}^{\text {high }}, \mathrm{Lgr}-5^{+}\end{array}$ & {$[97,115-119]$} \\
\hline Esophageal cancer & $\mathrm{CD} 271^{+}, \mathrm{CD} 44^{+} / \mathrm{CD} 24^{-}, \mathrm{CD} 90^{+}$ & {$[120-122]$} \\
\hline Gallbladder carcinoma and cholangiocarcinoma & $\mathrm{CD} 44^{+} / \mathrm{CD} 133^{+}, \mathrm{CD}_{2} 4^{+} / \mathrm{CD} 44^{+} / \mathrm{EpCAM}^{\text {high }}$ & {$[123,124]$} \\
\hline Gastric cancer & $\mathrm{CD} 44^{+} / \mathrm{CD} 54^{+}, \mathrm{CD} 90^{+}$ & {$[125,126]$} \\
\hline Glioma & Podoplanin ${ }^{+}, \mathrm{CD} 5^{+}, \mathrm{A} 2 \mathrm{~B} 5^{+}, \mathrm{CD} 44^{+}, \mathrm{CD} 133^{+}$ & {$[127-131]$} \\
\hline Head and neck squamous cell carcinomas & $\mathrm{CD}_{4} 4^{+}, \mathrm{ALDH}^{\text {high }}$ & {$[95,132]$} \\
\hline Liver cancer & $\begin{array}{l}\mathrm{CD} 0^{+} / \mathrm{CD} 44^{+}, \mathrm{CD}_{133^{+}} / \mathrm{CD} 44^{+}, \mathrm{EpCAM}^{+},{\mathrm{CD} 176^{+}}^{+} \\
\mathrm{CD} 13^{+},\end{array}$ & {$[90,112,133-136]$} \\
\hline Lung cancer & $\mathrm{CD} 133^{+}, \mathrm{CD} 44^{+}, \mathrm{CD} 176^{+}, \mathrm{CD} 56^{+}, \mathrm{CD} 0^{+}, \mathrm{CD} 66^{+}$ & {$[112,137-140]$} \\
\hline Melanoma & 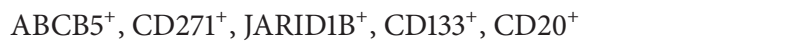 & {$[141-145]$} \\
\hline Nasopharyngeal cancer & $\mathrm{CD}_{4} 4^{+}, \mathrm{ALDH}^{+}, \mathrm{CD} 133^{+}$ & [146-148] \\
\hline Oral squamous carcinoma & $\mathrm{CD} 133^{+}, \mathrm{CD}_{4} 4^{+} / \mathrm{SSEA}-4^{+}$ & {$[149,150]$} \\
\hline Osteosarcomas & $\mathrm{CD}_{4} 4^{+} / \mathrm{CD} 105^{+} / \mathrm{Strol}^{+}, \mathrm{CD} 117^{+} / \mathrm{Stro} 1^{+}, \mathrm{Nes}^{+} / \mathrm{CD} 133^{+}, \mathrm{ABCA}^{+}$ & {$[151-154]$} \\
\hline Ovarian cancer & $\mathrm{CD} 133^{+}, \mathrm{CD} 44^{+}, \mathrm{CD} 117^{+}, \mathrm{CD} 44^{+} / \mathrm{CD} 24^{+}, \mathrm{CD}_{105^{+}}$ & [155-159] \\
\hline Pancreatic cancers & $\mathrm{CD} 44^{+} / \mathrm{CD} 24^{+} / \mathrm{ESA}^{+}, \mathrm{CD} 133^{+}, \mathrm{CXCR}^{+}$ & {$[96,160]$} \\
\hline Prostatic cancer & $\begin{array}{l}\mathrm{CD} 44^{+} / \text {Integrin } \alpha 2 \beta 1^{\text {high }} / \mathrm{CD} 133^{+}, \mathrm{Sca}^{+} 1^{+}, \mathrm{PSCA}^{+}, \\
\mathrm{CD}^{+} 0^{+},{\mathrm{CD} 164^{+}}\end{array}$ & {$[83,161-164]$} \\
\hline Skin squamous cell carcinoma & $\mathrm{CD} 34^{+}$, Integrin $\alpha 5 \beta 1^{\text {high }}$ & {$[165,166]$} \\
\hline
\end{tabular}

represses cancer propagation. It has also been discovered that a high level of $\mathrm{Bcl}-2$ in holoclones is tightly linked to syndecan-1 [167]. This finding is consistent with Lagadinou et al's discovery that the overexpression of Bcl-2 in acute myelogenous leukemia CSCs maintains the ROS synthesis rates at low levels and stabilizes the primitive cells in a quiescent state [168]. However, in Waldenstrom's macroglobulinemia, a lower ROS level is detected in $\mathrm{CD}_{20}^{-} \mathrm{CD} 138^{-}$cells compared with $\mathrm{CD} 20^{+} \mathrm{CD} 138^{-}$cells and $\mathrm{CD} 20^{+} \mathrm{CD} 138^{+}$cells [169].

\section{ROS Plays a Key Role in Anticancer Therapy}

The Warburg effect refers to the phenomenon that cancer cells gain energy primarily from glycolysis even under aerobic conditions, leading to increased ROS production [170]. Although the ROS levels, which are counteracted by elevated antioxidant defense mechanisms in cancer cells, are compatible with cellular biological functions, they are still higher than those observed in normal cells. Cancer cells may be more sensitive than normal cells to the accumulation of ROS, which offers an interesting therapeutic window [43]. Hence, directly increasing ROS to reach a threshold that is incompatible with cell viability and targeting the enhanced antioxidant mechanisms can selectively kill cancer cells, without affecting normal cells $[42,171]$. Despite the low level of ROS in CSCs and the active ROS detoxifying systems, elevating the concentration of ROS still has the ability to eliminate CSCs. The anticancer therapies by regulating ROS levels are shown in Table 2.

Many antineoplastic chemotherapeutic agents, including taxanes, vinca alkaloids, and platinum coordination complexes, are currently used to induce high levels of ROS, resulting in cell death [189-191]. Paclitaxel, a mitotic inhibitory drug, can stabilize microtubules and therefore interfere with the normal breakdown of microtubules during cell division. In breast cancer cells, paclitaxel causes the translocation of Racl, which positively regulates the activity of NOX, thereby promoting ROS generation. Paclitaxel-induced ROS is accumulated mainly outside the cell, provoking lethal damage to bystander cancer cells not exposed to paclitaxel, whereas the intracellular ROS levels remained unchanged [174]. The tumor suppressor promyelocytic leukemia protein (PML) has been demonstrated to play a critical role in the maintenance of quiescent chronic myeloid leukemia (CML) stem cells. Arsenic trioxide, which can induce ROS production and PML degradation, is introduced to eradicate CML stem cells [172]. Niclosamide, a potent antineoplastic 
TABLE 2: Anticancer therapies according to their different mechanisms in regulating ROS levels.

\begin{tabular}{llr}
\hline Mechanism & Therapy & Reference \\
\hline Generation of ROS & & $\begin{array}{l}\text { Arsenic trioxide, anthracyclines (doxorubicin, daunorubicin, or } \\
\text { epirubicin) }\end{array}$ \\
Mitochondrial respiratory chain & Paclitaxel, ionizing radiation, niclosamide, AGX-891, AG-221 \\
NOX & Celecoxib & {$[172,173]$} \\
COX & Buthionine sulfoximine, sulfasalazine, NOV-002, 6-anicotinamide, \\
Elimination of ROS & l-asparaginase, small molecule 968 \\
GSH & Auranofin \\
GSSH & Parthenolide \\
Myeloperoxidase & {$[179]$} \\
\hline
\end{tabular}

drug that inactivates the NF- $\kappa \mathrm{B}$ pathway and increases the ROS level, can preferentially kill progenitor/stem cells from acute myelogenous leukemia (AML) patients but spare those from normal bone marrow [175]. Consistent with this finding, parthenolide induces the apoptosis of CSCs in AML and blast crisis CML through mechanisms involving the inhibition of $\mathrm{NF}-\kappa \mathrm{B}$ and the proapoptotic activation of p53 and elevated ROS levels, which are likely obtained by a high level of myeloperoxidase [188].

At present, radiotherapy is widely used in various types of cancer treatments, mainly depending on ROS. Water radiolysis occurs in an extremely short period of time $\left(\sim 10^{-8} \mathrm{~s}\right)$ after ionizing radiation [192]. Several hours after exposure, intracellular ROS from biological sources are greatly enhanced [193]. Increased ROS generation in human lung carcinoma A549 cells exposed to X-irradiation is accompanied by an enhancement of the mitochondrial membrane potential, a promotion of mitochondrial respiration, and the maintenance of the ETC enzyme activities [194]. Furthermore, mitochondrial dysfunction and upregulation of NOX resulting from ionizing radiation contribute to persistent oxidative stress $[176,195]$. Tumor recurrence after radiation is attributed to preferential activation of the DNA damage checkpoint response and increases the DNA repair capacity and antioxidant defense [196, 197]. However, discrepant observations are provided by the recent finding that CSCs are more radiosensitive than non-CSCs [198, 199]. Such contradictory results may be due to the limited experimental techniques or the dynamic characteristics of CSCs, which require further clarification.

An enhanced GSH concentration within cancer cells appears to be actively involved in mechanisms of chemoradioresistance [200]. Due to the high content of GSH, tumor cells are more sensitive to drugs affecting GSH metabolism than normal cells [171]. Glutamate-cysteine ligase (GCL), as the rate-limiting enzyme in GSH synthesis, has been targeted in anticancer therapy. Buthionine sulfoximine (BSO), which can inhibit GCL activity, is the only clinically used drug to suppress de novo GSH synthesis [180]. In addition, sulfasalazine, an anti-inflammatory drug with specific $\mathrm{xCT}$ inhibitory activity, markedly reduces the cystine uptake, GSH level, and growth and viability of human pancreatic cancer cells and chronic lymphocytic leukemia cells both in vitro and in vivo $[181,182]$.

With the exception of GSH, thioredoxin is also an important component of intracellular redox systems. Auranofin is a gold-containing compound that functions as an antirheumatic drug and a thioredoxin inhibitor. Apoptosis is accompanied by an increased generation of $\mathrm{H}_{2} \mathrm{O}_{2}$ in ovarian cancer cells, which reflects the importance of the thioredoxin metabolism in tumor cell survival [187]. The simultaneous administration of auranofin and BSO has been validated to induce oxidative stress and clonogenic killing in human head and neck squamous carcinoma cells and to increase their sensitivity to epidermal growth factor receptor inhibitors [201].

In most cases, combined therapy lends credence to the success of cancer treatment. To cite some effective examples, ionizing radiation combined with arsenic trioxide improves the therapeutic efficacy in human prostate cancer cells because the combined treatment results in enhanced ROS production compared with each individual treatment, thereby provoking autophagy and apoptosis by inhibition of the Akt/mTOR signaling pathways [202]. Mechanistically, the sulforaphane and imatinib combined treatment can kill CD $34^{+}$CD $38^{-}$leukemia stem cells by inducing ROS production and decreasing the GSH level [203]. The combination of a CSC marker inhibitor with ROS-inducing therapy, such as chemo- and radiotherapy, can eradicate CSCs and thereby annihilate the whole tumor. In mouse xenograft models, the combination of a CD13 inhibitor with 5-fluorouracil therapy improves the treatment of liver cancer [90].

Because ROS are a central contributor in tumor occurrence and progression, antioxidants should prevent tumorigenesis through the elimination of excessive ROS and restoration of the redox balance [204]. In addition to their protective role as preventive reagents against cancer, there is evidence that antioxidant supplementation during chemotherapy presents promising potential to reduce dose-limiting toxicities [205]. A large epidemiologic study (including 132,837 women and men) conducted in China demonstrated that vitamin $\mathrm{E}$ intake, either from diet or supplements, may reduce the risk of liver cancer [206]. The opposite result was found in another large study conducted in England, which revealed 
that the combination of $\beta$-carotene and vitamin $A$ had no benefit and may have an adverse effect on the incidence and mortality of lung cancer [207]. In a two-stage mouse skin carcinogenesis model, a diet consisting of Nrf2 activators against oxidative stress significantly decreased the incidence of skin tumors [208]. In vitro experiments have proven that some nutrients with antioxidant characteristics, that is, vitamins $\mathrm{A}$ and $\mathrm{D}$, genistein, (-)-epigallocatechin-3-gallate, sulforaphane, curcumin, piperine, theanine, and choline, can modify the self-renewal capacity of CSCs [209]. That being said, further research is needed to confirm the utility of antioxidants in cancer prevention. The titration of the amount of antioxidant should be strictly controlled because toohigh or too-low levels may promote tumor survival and development.

\section{Conclusion}

CSCs have evolved to maintain a low level of intracellular ROS as a consequence of the modulation of redox systems, metabolic reprogramming, and reduced mitochondrial DNA levels. Increasing evidence proposes that a low concentration of ROS can maintain the stemness of CSCs and contribute to tumorigenesis and development. Therefore, HIF stabilization induced by ROS in CSCs plays a critical role. However, the underlying mechanisms in these processes remain to be elucidated in depth. There exist various systems for the regulation of ROS in CSCs, such as through CSC surface markers, and these help maintain the ROS at a favorable level. Consequently, the induction of oxidative stress appears to be a promising approach for the preferential killing of cancer cells, including CSCs. In addition, a more detailed investigation of therapies with direct or indirect effects on ROS will help define a made-to-order therapeutic schedule with a lower tendency toward promoting the development of resistance to treatment.

\section{Conflict of Interests}

The authors declare that there is no conflict of interests associated with the contents of this paper.

\section{References}

[1] S. C. Gupta, D. Hevia, S. Patchva, B. Park, W. Koh, and B. B. Aggarwal, "Upsides and downsides of reactive oxygen species for Cancer: the roles of reactive oxygen species in tumorigenesis, prevention, and therapy," Antioxidants and Redox Signaling, vol. 16, no. 11, pp. 1295-1322, 2012.

[2] D. Trachootham, J. Alexandre, and P. Huang, "Targeting cancer cells by ROS-mediated mechanisms: a radical therapeutic approach?" Nature Reviews Drug Discovery, vol. 8, no. 7, pp. 579-591, 2009.

[3] R. H. Burdon and C. Rice-Evans, "Free radicals and the regulation of mammalian cell proliferation," Free Radical Research Communications, vol. 6, no. 6, pp. 345-358, 1989.

[4] G. Storz and J. A. Imlay, "Oxidative stress," Current Opinion in Microbiology, vol. 2, no. 2, pp. 188-194, 1999.
[5] R. H. Burdon, "Superoxide and hydrogen peroxide in relation to mammalian cell proliferation," Free Radical Biology and Medicine, vol. 18, no. 4, pp. 775-794, 1995.

[6] T. Lapidot, C. Sirard, J. Vormoor et al., "A cell initiating human acute myeloid leukaemia after transplantation into SCID mice," Nature, vol. 367, no. 6464, pp. 645-648, 1994.

[7] L. V. Nguyen, R. Vanner, P. Dirks, and C. J. Eaves, "Cancer stem cells: an evolving concept," Nature Reviews Cancer, vol. 12, no. 2, pp. 133-143, 2012.

[8] M. F. Clarke, J. E. Dick, P. B. Dirks et al., "Cancer stem cellsperspectives on current status and future directions: AACR workshop on cancer stem cells," Cancer Research, vol. 66, no. 19, pp. 9339-9344, 2006.

[9] Y. Li, D. Kong, A. Ahmad, B. Bao, and F. H. Sarkar, "Pancreatic cancer stem cells: emerging target for designing novel therapy," Cancer Letters, vol. 338, no. 1, pp. 94-100, 2013.

[10] K. S. Koeneman, "Prostate cancer stem cells, telomerase biology, epigenetic modifiers, and molecular systemic therapy for the androgen-independent lethal phenotype," Urologic Oncology: Seminars and Original Investigations, vol. 24, no. 2, pp. 119-121, 2006.

[11] P. Economopoulou, V. G. Kaklamani, and K. Siziopikou, “The role of cancer stem cells in breast cancer initiation and progression: potential cancer stem cell-directed therapies," Oncologist, vol. 17, no. 11, pp. 1394-1401, 2012.

[12] P. B. Gupta, C. L. Chaffer, and R. A. Weinberg, "Cancer stem cells: mirage or reality?" Nature Medicine, vol. 15, no. 9, pp. 10101012, 2009.

[13] M. F. Clarke and M. Fuller, "Stem cells and cancer: two faces of eve," Cell, vol. 124, no. 6, pp. 1111-1115, 2006.

[14] M. Shackleton, E. Quintana, E. R. Fearon, and S. J. Morrison, "Heterogeneity in cancer: cancer stem cells versus clonal evolution," Cell, vol. 138, no. 5, pp. 822-829, 2009.

[15] M. Dean, T. Fojo, and S. Bates, "Tumour stem cells and drug resistance," Nature Reviews Cancer, vol. 5, no. 4, pp. 275-284, 2005.

[16] T. Reya, S. J. Morrison, M. F. Clarke, and I. L. Weissman, "Stem cells, cancer, and cancer stem cells," Nature, vol. 414, no. 6859, pp. 105-111, 2001.

[17] Y. Zhao, D. Y. Alakhova, and A. V. Kabanov, "Can nanomedicines kill cancer stem cells?” Advanced Drug Delivery Reviews, vol. 65, no. 13-14, pp. 1763-1783, 2013.

[18] R. S. Balaban, S. Nemoto, and T. Finkel, "Mitochondria, oxidants, and aging," Cell, vol. 120, no. 4, pp. 483-495, 2005.

[19] B. Chance, H. Sies, and A. Boveris, "Hydroperoxide metabolism in mammalian organs," Physiological Reviews, vol. 59, no. 3, pp. 527-605, 1979.

[20] S. Pervaiz, R. Taneja, and S. Ghaffari, "Oxidative stress regulation of stem and progenitor cells," Antioxidants \& Redox Signaling, vol. 11, no. 11, pp. 2777-2789, 2009.

[21] G. Cohen and P. Hochstein, "Glutathione peroxidase: the primary agent for the elimination of hydrogen peroxide in erythrocytes," Biochemistry, vol. 2, no. 6, pp. 1420-1428, 1963.

[22] B. Hofmann, H. J. Hecht, and L. Flohé, "Peroxiredoxins," Biological Chemistry, vol. 383, no. 3-4, pp. 347-364, 2002.

[23] C. Michiels, M. Raes, O. Toussaint, and J. Remacle, "Importance of SE-glutathione peroxidase, catalase, and Cu/Zn-SOD for cell survival against oxidative stress," Free Radical Biology and Medicine, vol. 17, no. 3, pp. 235-248, 1994.

[24] X. Shi, Y. Zhang, J. Zheng, and J. Pan, "Reactive oxygen species in cancer stem cells," Antioxidants and Redox Signaling, vol. 16, no. 11, pp. 1215-1228, 2012. 
[25] B. Halliwell, "Free radicals and antioxidants: updating a personal view," Nutrition Reviews, vol. 70, no. 5, pp. 257-265, 2012.

[26] W. Dröge, "Free radicals in the physiological control of cell function," Physiological Reviews, vol. 82, no. 1, pp. 47-95, 2002.

[27] L. Raj, T. Ide, A. U. Gurkar et al., "Selective killing of cancer cells by a small molecule targeting the stress response to ROS," Nature, vol. 475, no. 7355, pp. 231-234, 2011.

[28] Z. X. Chen and S. Pervaiz, "Bcl-2 induces pro-oxidant state by engaging mitochondrial respiration in tumor cells," Cell Death and Differentiation, vol. 14, no. 9, pp. 1617-1627, 2007.

[29] M. Sattler, T. Winkler, S. Verma et al., "Hematopoietic growth factors signal through the formation of reactive oxygen species," Blood, vol. 93, no. 9, pp. 2928-2935, 1999.

[30] M.-V. Clément and I. Stamenkovic, "Superoxide anion is a natural inhibitor of FAS-mediated cell death," The EMBO Journal, vol. 15, no. 2, pp. 216-225, 1996.

[31] G. Achanta, R. Sasaki, L. Feng et al., "Novel role of p53 in maintaining mitochondrial genetic stability through interaction with DNA Pol $\gamma$," The EMBO Journal, vol. 24, no. 19, pp. 3482-3492, 2005.

[32] S. Haghdoost, S. Czene, I. Näslund, S. Skog, and M. HarmsRingdahl, "Extracellular 8-oxo-dG as a sensitive parameter for oxidative stress in vivo and in vitro," Free Radical Research, vol. 39, no. 2, pp. 153-162, 2005.

[33] J. Pan, M. She, Z.-X. Xu, L. Sun, and S.-C. J. Yeung, "Farnesyltransferase inhibitors induce DNA damage via reactive oxygen species in human cancer cells," Cancer Research, vol. 65, no. 9, pp. 3671-3681, 2005.

[34] R. L. Wiseman, K.-T. Chin, C. M. Haynes et al., "Thioredoxinrelated protein 32 is an arsenite-regulated thiol reductase of the proteasome $19 \mathrm{~S}$ particle," The Journal of Biological Chemistry, vol. 284, no. 22, pp. 15233-15245, 2009.

[35] M. Nishikawa, "Reactive oxygen species in tumor metastasis," Cancer Letters, vol. 266, no. 1, pp. 53-59, 2008.

[36] C. C. Winterbourn, "Reconciling the chemistry and biology of reactive oxygen species," Nature Chemical Biology, vol. 4, no. 5, pp. 278-286, 2008.

[37] M. S. Cooke, M. D. Evans, M. Dizdaroglu, and J. Lunec, "Oxidative DNA damage: mechanisms, mutation, and disease," The FASEB Journal, vol. 17, no. 10, pp. 1195-1214, 2003.

[38] L. J. Marnett, “Oxyradicals and DNA damage," Carcinogenesis, vol. 21, no. 3, pp. 361-370, 2000.

[39] J. Rehman, "Empowering self-renewal and differentiation: the role of mitochondria in stem cells," Journal of Molecular Medicine, vol. 88, no. 10, pp. 981-986, 2010.

[40] C. D. L. Folmes, P. P. Dzeja, T. J. Nelson, and A. Terzic, "Metabolic plasticity in stem cell homeostasis and differentiation," Cell Stem Cell, vol. 11, no. 5, pp. 596-606, 2012.

[41] T. Lonergan, C. Brenner, and B. Bavister, "Differentiationrelated changes in mitochondrial properties as indicators of stem cell competence," Journal of Cellular Physiology, vol. 208, no. 1, pp. 149-153, 2006.

[42] V. Sosa, T. Moliné, R. Somoza, R. Paciucci, H. Kondoh, and M. E. LLeonart, "Oxidative stress and cancer: an overview," Ageing Research Reviews, vol. 12, no. 1, pp. 376-390, 2013.

[43] M. Diehn, R. W. Cho, N. A. Lobo et al., "Association of reactive oxygen species levels and radioresistance in cancer stem cells," Nature, vol. 458, no. 7239, pp. 780-783, 2009.

[44] L. S. Piao, W. Hur, T.-K. Kim et al., "CD133" liver cancer stem cells modulate radioresistance in human hepatocellular carcinoma," Cancer Letters, vol. 315, no. 2, pp. 129-137, 2012.
[45] X.-Q. Ye, G.-H. Wang, G.-J. Huang, X.-W. Bian, G.-S. Qian, and S.-C. Yu, "Heterogeneity of mitochondrial membrane potential: a novel tool to isolate and identify cancer stem cells from a tumor mass?" Stem Cell Reviews and Reports, vol. 7, no. 1, pp. 153-160, 2011.

[46] X.-Q. Ye, Q. Li, G.-H. Wang et al., "Mitochondrial and energy metabolism-related properties as novel indicators of lung cancer stem cells," International Journal of Cancer, vol. 129, no. 4, pp. 820-831, 2011.

[47] T. Ishimoto, O. Nagano, T. Yae et al., "CD44 variant regulates redox status in cancer cells by stabilizing the $\mathrm{xCT}$ subunit of system $\mathrm{xc}^{-}$and thereby promotes tumor growth," Cancer Cell, vol. 19, no. 3, pp. 387-400, 2011.

[48] J. M. Heddleston, Z. Li, J. D. Lathia, S. Bao, A. B. Hjelmeland, and J. N. Rich, "Hypoxia inducible factors in cancer stem cells," British Journal of Cancer, vol. 102, no. 5, pp. 789-795, 2010.

[49] J. Ye, D. Wu, P. Wu, Z. Chen, and J. Huang, "The cancer stem cell niche: cross talk between cancer stem cells and their microenvironment," Tumor Biology, vol. 35, no. 5, pp. 39453951, 2014.

[50] E. Louie, S. Nik, J.-S. Chen et al., "Identification of a stem-like cell population by exposing metastatic breast cancer cell lines to repetitive cycles of hypoxia and reoxygenation," Breast Cancer Research, vol. 12, no. 6, article R94, 2010.

[51] V. K. Bhaskara, I. Mohanam, J. S. Rao, and S. Mohanam, "Intermittent hypoxia regulates stem-like characteristics and differentiation of neuroblastoma cells," PLoS ONE, vol. 7, no. 2, Article ID e30905, 2012.

[52] P. Li, C. Zhou, L. Xu, and H. Xiao, "Hypoxia enhances stemness of cancer stem cells in glioblastoma: an in vitro study," International Journal of Medical Sciences, vol. 10, no. 4, pp. 399-407, 2013.

[53] J. Wei, A. Wu, L.-Y. Kong et al., "Hypoxia potentiates gliomamediated immunosuppression," PLoS ONE, vol. 6, no. 1, Article ID e16195, 2011.

[54] C. Feig, A. Gopinathan, A. Neesse, D. S. Chan, N. Cook, and D. A. Tuveson, "The pancreas cancer microenvironment," Clinical Cancer Research, vol. 18, no. 16, pp. 4266-4276, 2012.

[55] J. Pouysségur, F. Dayan, and N. M. Mazure, "Hypoxia signalling in cancer and approaches to enforce tumour regression," Nature, vol. 441, no. 7092, pp. 437-443, 2006.

[56] J. A. Bertout, S. A. Patel, and M. C. Simon, "The impact of $\mathrm{O}_{2}$ availability on human cancer," Nature Reviews Cancer, vol. 8, no. 12, pp. 967-975, 2008.

[57] G. Yuan, J. Nanduri, S. Khan, G. L. Semenza, and N. R. Prabhakar, "Induction of HIF-alpha expression by intermittent hypoxia: involvement of NADPH oxidase, $\mathrm{Ca}^{2+}$ signaling, prolyl hydroxylases, and mTOR," Journal of Cellular Physiology, vol. 217, no. 3, pp. 674-685, 2008.

[58] T. Klimova and N. S. Chandel, "Mitochondrial complex III regulates hypoxic activation of HIF," Cell Death and Differentiation, vol. 15, no. 4, pp. 660-666, 2008.

[59] N. Rohwer and T. Cramer, "Hypoxia-mediated drug resistance: novel insights on the functional interaction of HIFs and cell death pathways," Drug Resistance Updates, vol. 14, no. 3, pp. 191201, 2011.

[60] T. Zhao, Y. Zhu, A. Morinibu et al., "HIF-1-mediated metabolic reprogramming reduces ROS levels and facilitates the metastatic colonization of cancers in lungs," Scientific Reports, vol. 4, article 3793, 2014. 
[61] J. A. Bertout, A. J. Majmundar, J. D. Gordan et al., "HIF2alpha inhibition promotes $\mathrm{p} 53$ pathway activity, tumor cell death, and radiation responses," Proceedings of the National Academy of Sciences of the United States of America, vol. 106, no. 34, pp. 14391-14396, 2009.

[62] J. D. Gordan, P. Lal, V. R. Dondeti et al., "HIF-alpha effects on c-Myc distinguish two subtypes of sporadic VHL-deficient clear cell renal carcinoma," Cancer Cell, vol. 14, no. 6, pp. 435-446, 2008.

[63] M. Scortegagna, K. Ding, Y. Oktay et al., "Multiple organ pathology, metabolic abnormalities and impaired homeostasis of reactive oxygen species in EpasI ${ }^{-1-}$ mice," Nature Genetics, vol. 35, no. 4, pp. 331-340, 2003.

[64] L. Holmquist-Mengelbier, E. Fredlund, T. Löfstedt et al., "Recruitment of HIF- $1 \alpha$ and HIF- $2 \alpha$ to common target genes is differentially regulated in neuroblastoma: HIF- $2 \alpha$ promotes an aggressive phenotype," Cancer Cell, vol. 10, no. 5, pp. 413-423, 2006.

[65] Z. Li, S. Bao, Q. Wu et al., "Hypoxia-inducible factors regulate tumorigenic capacity of glioma stem cells," Cancer Cell, vol. 15, no. 6, pp. 501-513, 2009.

[66] H. Iida, M. Suzuki, R. Goitsuka, and H. Ueno, "Hypoxia induces CD133 expression in human lung cancer cells by up-regulation of OCT3/4 and SOX2," International Journal of Oncology, vol. 40, no. 1, pp. 71-79, 2012.

[67] M. Y. Koh and G. Powis, "Passing the baton: the HIF switch," Trends in Biochemical Sciences, vol. 37, no. 9, pp. 364-372, 2012.

[68] M. Y. Koh, R. Lemos Jr., X. Liu, and G. Powis, "The hypoxia-associated factor switches cells from HIF- $1 \alpha$ - to HIF$2 \alpha$-dependent signaling promoting stem cell characteristics, aggressive tumor growth and invasion," Cancer Research, vol. 71, no. 11, pp. 4015-4027, 2011.

[69] C. Branco-Price, N. Zhang, M. Schnelle et al., "Endothelial cell HIF- $1 \alpha$ and HIF- $2 \alpha$ differentially regulate metastatic success," Cancer Cell, vol. 21, no. 1, pp. 52-65, 2012.

[70] H. E. Lee, J. H. Kim, Y. J. Kim et al., "An increase in cancer stem cell population after primary systemic therapy is a poor prognostic factor in breast cancer," British Journal of Cancer, vol. 104, no. 11, pp. 1730-1738, 2011.

[71] C. L. Chaffer, I. Brueckmann, C. Scheel et al., "Normal and neoplastic nonstem cells can spontaneously convert to a stemlike state," Proceedings of the National Academy of Sciences of the United States of America, vol. 108, no. 19, pp. 7950-7955, 2011.

[72] C. Odoux, H. Fohrer, T. Hoppo et al., "A stochastic model for cancer stem cell origin in metastatic colon cancer," Cancer Research, vol. 68, no. 17, pp. 6932-6941, 2008.

[73] I. Malanchi, A. Santamaria-Martínez, E. Susanto et al., "Interactions between cancer stem cells and their niche govern metastatic colonization," Nature, vol. 481, no. 7379, pp. 85-91, 2012.

[74] C. Scheel, E. N. Eaton, S. H.-J. Li et al., "Paracrine and autocrine signals induce and maintain mesenchymal and stem cell states in the breast," Cell, vol. 145, no. 6, pp. 926-940, 2011.

[75] G. Driessens, B. Beck, A. Caauwe, B. D. Simons, and C. Blanpain, "Defining the mode of tumour growth by clonal analysis," Nature, vol. 488, no. 7412, pp. 527-530, 2012.

[76] J. Mathieu, Z. Zhang, W. Zhou et al., "HIF induces human embryonic stem cell markers in cancer cells," Cancer Research, vol. 71, no. 13, pp. 4640-4652, 2011.
[77] B. Krishnamachary, M.-F. Penet, S. Nimmagadda et al., "Hypoxia regulates CD44 and its variant isoforms through HIF$1 \alpha$ in triple negative breast cancer," PLoS ONE, vol. 7, no. 8, Article ID e44078, 2012.

[78] N. Platet, S. Y. Liu, M. E. Atifi et al., "Influence of oxygen tension on CD133 phenotype in human glioma cell cultures," Cancer Letters, vol. 258, no. 2, pp. 286-290, 2007.

[79] F. M. Gabhann and A. S. Popel, "Systems biology of vascular endothelial growth factors," Microcirculation, vol. 15, no. 8, pp. 715-738, 2008.

[80] J. M. Heddleston, Z. Li, R. E. McLendon, A. B. Hjelmeland, and J. N. Rich, "The hypoxic microenvironment maintains glioblastoma stem cells and promotes reprogramming towards a cancer stem cell phenotype," Cell Cycle, vol. 8, no. 20, pp. 32743284, 2009.

[81] H. Schepers, D. van Gosliga, A. T. J. Wierenga, B. J. L. Eggen, J. J. Schuringa, and E. Vellenga, "STAT5 is required for long-term maintenance of normal and leukemic human stem/progenitor cells," Blood, vol. 110, no. 8, pp. 2880-2888, 2007.

[82] J. Stingl, P. Eirew, I. Ricketson et al., "Purification and unique properties of mammary epithelial stem cells," Nature, vol. 439, no. 7079, pp. 993-997, 2006.

[83] A. T. Collins, P. A. Berry, C. Hyde, M. J. Stower, and N. J. Maitland, "Prospective identification of tumorigenic prostate cancer stem cells," Cancer Research, vol. 65, no. 23, pp. $10946-$ 10951, 2005.

[84] S. K. Singh, C. Hawkins, I. D. Clarke et al., "Identification of human brain tumour initiating cells," Nature, vol. 432, no. 7015, pp. 396-401, 2004.

[85] W. Xu, B. G. Debeb, L. Lacerda, J. Li, and W. A. Woodward, "Tetrandrine, a compound common in Chinese traditional medicine, preferentially kills breast cancer tumor initiating cells (TICs) in vitro," Cancers, vol. 3, no. 2, pp. 2274-2285, 2011.

[86] N. E. Bhola, J. M. Balko, T. C. Dugger et al., “TGF- $\beta$ inhibition enhances chemotherapy action against triple-negative breast cancer," The Journal of Clinical Investigation, vol. 123, no. 3, pp. 1348-1358, 2013.

[87] M. Natsuizaka, H. Kinugasa, S. Kagawa et al., "IGFBP3 promotes esophageal cancer growth by suppressing oxidative stress in hypoxic tumor microenvironment," The American Journal of Cancer Research, vol. 4, no. 1, pp. 29-41, 2014.

[88] Y. Mishima, Y. Matsumoto-Mishima, Y. Terui et al., "Leukemic cell-surface CD13/aminopeptidase $\mathrm{N}$ and resistance to apoptosis mediated by endothelial cells," Journal of the National Cancer Institute, vol. 94, no. 13, pp. 1020-1028, 2002.

[89] H. M. Kim, N. Haraguchi, H. Ishii et al., "Increased CD13 expression reduces reactive oxygen species, promoting survival of liver cancer stem cells via an epithelial-mesenchymal transition-like phenomenon," Annals of Surgical Oncology, vol. 19, no. 3, supplement, pp. S539-S548, 2012.

[90] N. Haraguchi, H. Ishii, K. Mimori et al., "CD13 is a therapeutic target in human liver cancer stem cells," The Journal of Clinical Investigation, vol. 120, no. 9, pp. 3326-3339, 2010.

[91] L. E. Ailles and I. L. Weissman, "Cancer stem cells in solid tumors," Current Opinion in Biotechnology, vol. 18, no. 5, pp. 460-466, 2007.

[92] M. Zöller, "CD44: can a cancer-initiating cell profit from an abundantly expressed molecule?" Nature Reviews Cancer, vol. 11, no. 4, pp. 254-267, 2011.

[93] N. A. Lobo, Y. Shimono, D. Qian, and M. F. Clarke, "The biology of cancer stem cells," Annual Review of Cell and Developmental Biology, vol. 23, no. 1, pp. 675-699, 2007. 
[94] M. Al-Hajj, M. S. Wicha, A. Benito-Hernandez, S. J. Morrison, and M. F. Clarke, "Prospective identification of tumorigenic breast cancer cells," Proceedings of the National Academy of Sciences of the United States of America, vol. 100, no. 7, pp. 39833988, 2003.

[95] M. E. Prince, R. Sivanandan, A. Kaczorowski et al., "Identification of a subpopulation of cells with cancer stem cell properties in head and neck squamous cell carcinoma," Proceedings of the National Academy of Sciences of the United States of America, vol. 104, no. 3, pp. 973-978, 2007.

[96] P. C. Hermann, S. L. Huber, T. Herrler et al., "Distinct populations of cancer stem cells determine tumor growth and metastatic activity in human pancreatic cancer," Cell Stem Cell, vol. 1, no. 3, pp. 313-323, 2007.

[97] P. Dalerba, S. J. Dylla, I.-K. Park et al., "Phenotypic characterization of human colorectal cancer stem cells," Proceedings of the National Academy of Sciences of the United States of America, vol. 104, no. 24, pp. 10158-10163, 2007.

[98] T. Ishimoto, H. Sugihara, M. Watanabe et al., "Macrophagederived reactive oxygen species suppress miR-328 targeting CD44 in cancer cells and promote redox adaptation," Carcinogenesis, vol. 35, no. 5, pp. 1003-1011, 2014.

[99] O. Nagano, S. Okazaki, and H. Saya, "Redox regulation in stemlike cancer cells by CD44 variant isoforms," Oncogene, vol. 32, no. 44, pp. 5191-5198, 2013.

[100] D. Bonnet and J. E. Dick, "Human acute myeloid leukemia is organized as a hierarchy that originates from a primitive hematopoietic cell," Nature Medicine, vol. 3, no. 7, pp. 730-737, 1997.

[101] L. Jin, K. J. Hope, Q. Zhai, F. Smadja-Joffe, and J. E. Dick, "Targeting of CD44 eradicates human acute myeloid leukemic stem cells," Nature Medicine, vol. 12, no. 10, pp. 1167-1174, 2006.

[102] L. Jin, E. M. Lee, H. S. Ramshaw et al., "Monoclonal antibodymediated targeting of CD123, IL-3 receptor $\alpha$ chain, eliminates human acute myeloid leukemic stem cells," Cell Stem Cell, vol. 5, no. 1, pp. 31-42, 2009.

[103] R. Majeti, M. P. Chao, A. A. Alizadeh et al., "CD47 is an adverse prognostic factor and therapeutic antibody target on human acute myeloid leukemia stem cells," Cell, vol. 138, no. 2, pp. 286299, 2009.

[104] C. T. Jordan, D. Upchurch, S. J. Szilvassy et al., "The interleukin3 receptor alpha chain is a unique marker for human acute myelogenous leukemia stems cells," Leukemia, vol. 14, no. 10, pp. 1777-1784, 2000.

[105] C. V. Cox, R. S. Evely, A. Oakhill, D. H. Pamphilon, N. J. Goulden, and A. Blair, "Characterization of acute lymphoblastic leukemia progenitor cells," Blood, vol. 104, no. 9, pp. 2919-2925, 2004.

[106] Y. M. Yang and J. W. Chang, "Bladder cancer initiating cells (BCICs) are among EMA ${ }^{-} \mathrm{CD} 44 \mathrm{v6}^{+}$subset: novel methods for isolating undetermined cancer stem (initiating) cells," Cancer Investigation, vol. 26, no. 7, pp. 725-733, 2008.

[107] X. He, L. Marchionni, D. E. Hansel et al., "Differentiation of a highly tumorigenic basal cell compartment in urothelial carcinoma," Stem Cells, vol. 27, no. 7, pp. 1487-1495, 2009.

[108] K. S. Chan, I. Espinosa, M. Chao et al., "Identification, molecular characterization, clinical prognosis, and therapeutic targeting of human bladder tumor-initiating cells," Proceedings of the National Academy of Sciences of the United States of America, vol. 106, no. 33, pp. 14016-14021, 2009.

[109] C. Ginestier, M. H. Hur, E. Charafe-Jauffret et al., "ALDH1 is a marker of normal and malignant human mammary stem cells and a predictor of poor clinical outcome," Cell Stem Cell, vol. 1, no. 5, pp. 555-567, 2007.

[110] J.-X. Xu, E. Morii, Y. Liu et al., "High tolerance to apoptotic stimuli induced by serum depletion and ceramide in sidepopulation cells: high expression of CD55 as a novel character for side-population," Experimental Cell Research, vol. 313, no. 9, pp. 1877-1885, 2007.

[111] M. J. Meyer, J. M. Fleming, A. F. Lin, S. A. Hussnain, E. Ginsburg, and B. K. Vonderhaar, "CD $44{ }^{\text {pos }} \mathrm{CD} 49 \mathrm{f}^{\text {hi }} \mathrm{CD} 133 / 2^{\text {hi }}$ defines xenograft-initiating cells in estrogen receptor-negative breast cancer," Cancer Research, vol. 70, no. 11, pp. 4624-4633, 2010.

[112] W.-M. Lin, U. Karsten, S. Goletz, R.-C. Cheng, and Y. Cao, "Expression of CD176 (Thomsen-Friedenreich antigen) on lung, breast and liver cancer-initiating cells," International Journal of Experimental Pathology, vol. 92, no. 2, pp. 97-105, 2011.

[113] W. Gu, E. Yeo, N. McMillan, and C. Yu, "Silencing oncogene expression in cervical cancer stem-like cells inhibits their cell growth and self-renewal ability," Cancer Gene Therapy, vol. 18, no. 12, pp. 897-905, 2011.

[114] J. López, A. Poitevin, V. Mendoza-Martínez, C. Pérez-Plasencia, and A. García-Carrancá, "Cancer-initiating cells derived from established cervical cell lines exhibit stem-cell markers and increased radioresistance," BMC Cancer, vol. 12, article 48, 2012.

[115] L. Ricci-Vitiani, D. G. Lombardi, E. Pilozzi et al., "Identification and expansion of human colon-cancer-initiating cells," Nature, vol. 445, no. 7123, pp. 111-115, 2007.

[116] K. Kemper, C. Grandela, and J. P. Medema, "Molecular identification and targeting of colorectal cancer stem cells.", Oncotarget, vol. 1, no. 6, pp. 387-395, 2010.

[117] C. A. O'Brien, A. Pollett, S. Gallinger, and J. E. Dick, “A human colon cancer cell capable of initiating tumour growth in immunodeficient mice," Nature, vol. 445, no. 7123, pp. 106-110, 2007.

[118] E. H. Huang, M. J. Hynes, T. Zhang et al., "Aldehyde dehydrogenase 1 is a marker for normal and malignant human colonic stem cells (SC) and tracks SC overpopulation during colon tumorigenesis," Cancer Research, vol. 69, no. 8, pp. 3382-3389, 2009.

[119] N. Barker, R. A. Ridgway, J. H. van Es et al., "Crypt stem cells as the cells-of-origin of intestinal cancer," Nature, vol. 457, no. 7229, pp. 608-611, 2009.

[120] T. Okumura, S. Tsunoda, Y. Mori et al., "The biological role of the low-affinity p75 neurotrophin receptor in esophageal squamous cell carcinoma," Clinical Cancer Research, vol. 12, no. 17, pp. 5096-5103, 2006.

[121] J. K. Smit, H. Faber, M. Niemantsverdriet et al., "Prediction of response to radiotherapy in the treatment of esophageal cancer using stem cell markers," Radiotherapy and Oncology, vol. 107, no. 3, pp. 434-441, 2013.

[122] K. H. Tang, Y. D. Dai, M. Tong et al., "A CD90 ${ }^{+}$tumor-initiating cell population with an aggressive signature and metastatic capacity in esophageal cancer," Cancer Research, vol. 73, no. 7, pp. 2322-2332, 2013.

[123] C. Shi, R. Tian, M. Wang et al., "CD $44^{+} \mathrm{CD} 133^{+}$population exhibits cancer stem cell-like characteristics in human gallbladder carcinoma," Cancer Biology \& Therapy, vol. 10, no. 11, pp. 1182-1190, 2010.

[124] M. Wang, J. Xiao, J. Jiang, and R. Qin, "CD133 and ALDH may be the molecular markers of cholangiocarcinoma stem cells," 
International Journal of Cancer, vol. 128, no. 8, pp. 1996-1997, 2011.

[125] T. Chen, K. Yang, J. Yu et al., "Identification and expansion of cancer stem cells in tumor tissues and peripheral blood derived from gastric adenocarcinoma patients," Cell Research, vol. 22, no. 1, pp. 248-258, 2012.

[126] J. Jiang, Y. Zhang, S. Chuai et al., “Trastuzumab (herceptin) targets gastric cancer stem cells characterized by CD90 phenotype," Oncogene, vol. 31, no. 6, pp. 671-682, 2012.

[127] K. Christensen, C. Aaberg-Jessen, C. Andersen, D. Goplen, R. Bjerkvig, and B. W. Kristensen, "Immunohistochemical expression of stem cell, endothelial cell, and chemosensitivity markers in primary glioma spheroids cultured in serum-containing and serum-free medium," Neurosurgery, vol. 66, no. 5, pp. 933-947, 2010.

[128] K. Mishima, Y. Kato, M. K. Kaneko, R. Nishikawa, T. Hirose, and M. Matsutani, "Increased expression of podoplanin in malignant astrocytic tumors as a novel molecular marker of malignant progression," Acta Neuropathologica, vol. 111, no. 5, pp. 483-488, 2006.

[129] M. J. Son, K. Woolard, D.-H. Nam, J. Lee, and H. A. Fine, "SSEA1 is an enrichment marker for tumor-initiating cells in human glioblastoma," Cell Stem Cell, vol. 4, no. 5, pp. 440-452, 2009.

[130] A. Tchoghandjian, N. Baeza, C. Colin et al., "A2B5 cells from human glioblastoma have cancer stem cell properties," Brain Pathology, vol. 20, no. 1, pp. 211-221, 2010.

[131] J. Anido, A. Sáez-Borderías, A. Gonzàlez-Juncà et al., “TGF$\beta$ receptor inhibitors target the $\mathrm{CD} 44$ high/Idlhigh gliomainitiating cell population in human glioblastoma," Cancer Cell, vol. 18, no. 6, pp. 655-668, 2010.

[132] Y.-C. Chen, D.-T. Chen, Y.-W. Chen et al., "Aldehyde dehydrogenase 1 is a putative marker for cancer stem cells in head and neck squamous cancer," Biochemical and Biophysical Research Communications, vol. 385, no. 3, pp. 307-313, 2009.

[133] Z. F. Yang, D. W. Ho, M. N. Ng et al., "Significance of $\mathrm{CD}^{+} 0^{+}$ cancer stem cells in human liver cancer," Cancer Cell, vol. 13, no. 2, pp. 153-166, 2008.

[134] Z. Zhu, X. Hao, M. Yan et al., "Cancer stem/progenitor cells are

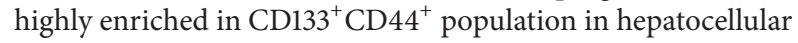
carcinoma," International Journal of Cancer, vol. 126, no. 9, pp. 2067-2078, 2010.

[135] B. Terris, C. Cavard, and C. Perret, "EpCAM, a new marker for cancer stem cells in hepatocellular carcinoma," Journal of Hepatology, vol. 52, no. 2, pp. 280-281, 2010.

[136] O. Kimura, T. Takahashi, N. Ishii et al., "Characterization of the epithelial cell adhesion molecule (EpCAM) ${ }^{+}$cell population in hepatocellular carcinoma cell lines," Cancer Science, vol. 101, no. 10, pp. 2145-2155, 2010.

[137] A. Eramo, F. Lotti, G. Sette et al., "Identification and expansion of the tumorigenic lung cancer stem cell population," Cell Death and Differentiation, vol. 15, no. 3, pp. 504-514, 2008.

[138] E. L.-H. Leung, R. R. Fiscus, J. W. Tung et al., "Non-small cell lung cancer cells expressing CD44 are enriched for stem celllike properties," PLoS ONE, vol. 5, no. 11, Article ID e14062, 2010.

[139] C. D. Salcido, A. Larochelle, B. J. Taylor, C. E. Dunbar, and L. Varticovski, "Molecular characterisation of side population cells with cancer stem cell-like characteristics in small-cell lung cancer," British Journal of Cancer, vol. 102, no. 11, pp. 1636-1644, 2010.
[140] W. C. Zhang, N. Shyh-Chang, H. Yang et al., "Glycine decarboxylase activity drives non-small cell lung cancer tumorinitiating cells and tumorigenesis," Cell, vol.148, no. 1-2, pp. 259272, 2012.

[141] A. D. Boiko, O. V. Razorenova, M. van de Rijn et al., "Human melanoma-initiating cells express neural crest nerve growth factor receptor CD271," Nature, vol. 466, no. 7302, pp. 133-137, 2010.

[142] D. Fang, M. Herlyn, T. K. Nguyen et al., "A tumorigenic subpopulation with stem cell properties in melanomas," Cancer Research, vol. 65, no. 20, pp. 9328-9337, 2005.

[143] E. Quintana, M. Shackleton, H. R. Foster et al., "Phenotypic heterogeneity among tumorigenic melanoma cells from patients that is reversible and not hierarchically organized," Cancer Cell, vol. 18, no. 5, pp. 510-523, 2010.

[144] A. Roesch, M. Fukunaga-Kalabis, E. C. Schmidt et al., "A temporarily distinct subpopulation of slow-cycling melanoma cells is required for continuous tumor growth," Cell, vol. 141, no. 4, pp. 583-594, 2010.

[145] T. Schatton, G. F. Murphy, N. Y. Frank et al., "Identification of cells initiating human melanomas," Nature, vol. 451, no. 7176, pp. 345-349, 2008.

[146] J. Su, X.-H. Xu, Q. Huang et al., "Identification of cancer stemlike $\mathrm{CD} 44^{+}$cells in human nasopharyngeal carcinoma cell line," Archives of Medical Research, vol. 42, no. 1, pp. 15-21, 2011.

[147] A. Wu, W. Luo, Q. Zhang et al., "Aldehyde dehydrogenase 1, a functional marker for identifying cancer stem cells in human nasopharyngeal carcinoma," Cancer Letters, vol. 330, no. 2, pp. 181-189, 2013.

[148] H.-W. Zhuang, T.-T. Mo, W.-J. Hou et al., "Biological characteristics of $\mathrm{CD}_{133^{+}}$cells in nasopharyngeal carcinoma," Oncology Reports, vol. 30, no. 1, pp. 57-63, 2013.

[149] Q. Zhang, S. Shi, Y. Yen, J. Brown, J. Q. Ta, and A. D. Le, "A subpopulation of $\mathrm{CD}_{133^{+}}$cancer stem-like cells characterized in human oral squamous cell carcinoma confer resistance to chemotherapy," Cancer Letters, vol. 289, no. 2, pp. 151-160, 2010.

[150] Z. Noto, T. Yoshida, M. Okabe et al., "CD44 and SSEA-4 positive cells in an oral cancer cell line HSC-4 possess cancer stem-like cell characteristics," Oral Oncology, vol. 49, no. 8, pp. 787-795, 2013.

[151] C. P. Gibbs, V. G. Kukekov, J. D. Reith et al., "Stem-like cells in bone sarcomas: implications for tumorigenesis," Neoplasia, vol. 7, no. 11, pp. 967-976, 2005.

[152] A. S. Adhikari, N. Agarwal, B. M. Wood et al., "CD117 and Stro1 identify osteosarcoma tumor-initiating cells associated with metastasis and drug resistance," Cancer Research, vol. 70, no. 11, pp. 4602-4612, 2010.

[153] R. Veselska, M. Hermanova, T. Loja et al., "Nestin expression in osteosarcomas and derivation of nestin/CD133 positive osteosarcoma cell lines," BMC Cancer, vol. 8, article 300, 2008.

[154] V. Saini, C. D. Hose, A. Monks et al., "Identification of CBX3 and ABCA5 as putative biomarkers for tumor stem cells in osteosarcoma," PLoS ONE, vol. 7, no. 8, Article ID e41401, 2012.

[155] M. D. Curley, V. A. Therrien, C. L. Cummings et al., "CD133 expression defines a tumor initiating cell population in primary human ovarian cancer," Stem Cells, vol. 27, no. 12, pp. 2875-2883, 2009.

[156] S. Zhang, C. Balch, M. W. Chan et al., "Identification and characterization of ovarian cancer-initiating cells from primary human tumors," Cancer Research, vol. 68, no. 11, pp. 4311-4320, 2008. 
[157] A. J. Ziebarth, S. Nowsheen, A. D. Steg et al., "Endoglin (CD105) contributes to platinum resistance and is a target for tumorspecific therapy in epithelial ovarian cancer," Clinical Cancer Research, vol. 19, no. 1, pp. 170-182, 2013.

[158] K. Meirelles, L. A. Benedict, D. Dombkowski et al., "Human ovarian cancer stem/progenitor cells are stimulated by doxorubicin but inhibited by Mullerian inhibiting substance," Proceedings of the National Academy of Sciences of the United States of America, vol. 109, no. 7, pp. 2358-2363, 2012.

[159] L. Luo, J. Zeng, B. Liang et al., "Ovarian cancer cells with the CD117 phenotype are highly tumorigenic and are related to chemotherapy outcome," Experimental and Molecular Pathology, vol. 91, no. 2, pp. 596-602, 2011.

[160] C. Li, C. J. Lee, and D. M. Simeone, "Identification of human pancreatic cancer stem cells," in Cancer Stem Cells, J. S. Yu, Ed., vol. 568 of Methods in Molecular Biology, pp. 161-173, Humana Press, Clifton, NJ, USA, 2009.

[161] L. Xin, D. A. Lawson, and O. N. Witte, “The Sca-1 cell surface marker enriches for a prostate-regenerating cell subpopulation that can initiate prostate tumorigenesis," Proceedings of the National Academy of Sciences of the United States of America, vol. 102, no. 19, pp. 6942-6947, 2005.

[162] R. E. Reiter, Z. Gu, T. Watabe et al., "Prostate stem cell antigen: a cell surface marker overexpressed in prostate cancer," Proceedings of the National Academy of Sciences of the United States of America, vol. 95, no. 4, article 1735, 1998.

[163] M. A. Dall'Era, L. D. True, A. F. Siegel, M. P. Porter, T. M. Sherertz, and A. Y. Liu, "Differential expression of CD10 in prostate cancer and its clinical implication," BMC Urology, vol. 7, article 3, 2007.

[164] A. M. Havens, Y. H. Jung, Y. X. Sun et al., "The role of sialomucin CD164 (MGC-24v or endolyn) in prostate cancer metastasis," BMC Cancer, vol. 6, article 195, 2006.

[165] I. Malanchi, H. Peinado, D. Kassen et al., "Cutaneous cancer stem cell maintenance is dependent on $\beta$-catenin signalling," Nature, vol. 452, no. 7187, pp. 650-653, 2008.

[166] M. Schober and E. Fuchs, "Tumor-initiating stem cells of squamous cell carcinomas and their control by TGF- $\beta$ and integrin/focal adhesion kinase (FAK) signaling," Proceedings of the National Academy of Sciences of the United States of America, vol. 108, no. 26, pp. 10544-10549, 2011.

[167] K. Shimada, S. Anai, T. Fujii, N. Tanaka, K. Fujimoto, and N. Konishi, "Syndecan-1 (CD138) contributes to prostate cancer progression by stabilizing tumour-initiating cells," The Journal of Pathology, vol. 231, no. 4, pp. 495-504, 2013.

[168] E. D. Lagadinou, A. Sach, K. Callahan et al., "BCL-2 inhibition targets oxidative phosphorylation and selectively eradicates quiescent human leukemia stem cells," Cell Stem Cell, vol. 12, no. 3, pp. 329-341, 2013.

[169] N. Wada, M. Zhan, Y. Hori, K. Honma, J.-I. Ikeda, and E. Morii, "Characterization of subpopulation lacking both B-cell and plasma cell markers in Waldenstrom macroglobulinemia cell line," Laboratory Investigation, vol. 94, no. 1, pp. 79-88, 2014.

[170] R. A. Cairns, I. S. Harris, and T. W. Mak, "Regulation of cancer cell metabolism," Nature Reviews Cancer, vol. 11, no. 2, pp. 8595, 2011.

[171] C. Gorrini, I. S. Harris, and T. W. Mak, "Modulation of oxidative stress as an anticancer strategy," Nature Reviews Drug Discovery, vol. 12, no. 12, pp. 931-947, 2013.

[172] K. Ito, R. Bernardi, A. Morotti et al., "PML targeting eradicates quiescent leukaemia-initiating cells," Nature, vol. 453, no. 7198, pp. 1072-1078, 2008.
[173] T. Šimůnek, M. Štěrba, O. Popelová, M. Adamcová, R. Hrdina, and V. Gerši, "Anthracycline-induced cardiotoxicity: overview of studies examining the roles of oxidative stress and free cellular iron," Pharmacological Reports, vol. 61, no. 1, pp. 154171, 2009.

[174] J. Alexandre, Y. Hu, W. Lu, H. Pelicano, and P. Huang, "Novel action of paclitaxel against cancer cells: bystander effect mediated by reactive oxygen species," Cancer Research, vol. 67, no. 8, pp. 3512-3517, 2007.

[175] Y. Jin, Z. Lu, K. Ding et al., "Antineoplastic mechanisms of niclosamide in acute myelogenous leukemia stem cells: inactivation of the NF- $\kappa \mathrm{B}$ pathway and generation of reactive oxygen species," Cancer Research, vol. 70, no. 6, pp. 2516-2527, 2010.

[176] T. Yoshida, S. Goto, M. Kawakatsu, Y. Urata, and T.-S. Li, "Mitochondrial dysfunction, a probable cause of persistent oxidative stress after exposure to ionizing radiation," Free Radical Research, vol. 46, no. 2, pp. 147-153, 2012.

[177] J.-A. Losman, R. E. Looper, P. Koivunen et al., "(R)-2hydroxyglutarate is sufficient to promote leukemogenesis and its effects are reversible," Science, vol. 340, no. 6127, pp. 1621$1625,2013$.

[178] F. Wang, J. Travins, B. DeLaBarre et al., "Targeted inhibition of mutant IDH2 in leukemia cells induces cellular differentiation," Science, vol. 340, no. 6132, pp. 622-626, 2013.

[179] J. Zhu, X. Song, H.-P. Lin et al., "Using cyclooxygenase2 inhibitors as molecular platforms to develop a new class of apoptosis-inducing agents," Journal of the National Cancer Institute, vol. 94, no. 23, pp. 1745-1757, 2002.

[180] O. W. Griffith, "Mechanism of action, metabolism, and toxicity of buthionine sulfoximine and its higher homologs, potent inhibitors of glutathione synthesis," The Journal of Biological Chemistry, vol. 257, no. 22, pp. 13704-13712, 1982.

[181] M. Lo, V. Ling, C. Low, Y. Z. Wang, and P. W. Gout, "Potential use of the anti-inflammatory drug, sulfasalazine, for targeted therapy of pancreatic cancer," Current Oncology, vol. 17, no. 3, pp. 9-16, 2010.

[182] P. W. Gout, A. R. Buckley, C. R. Simms, and N. Bruchovsky, "Sulfasalazine, a potent suppressor of lymphoma growth by inhibition of the $X_{c}{ }^{-}$cystine transporter: a new action for an old drug," Leukemia, vol. 15, no. 10, pp. 1633-1640, 2001.

[183] A. J. Montero, C. M. Diaz-Montero, Y. E. Deutsch et al., "Phase 2 study of neoadjuvant treatment with NOV-002 in combination with doxorubicin and cyclophosphamide followed by docetaxel in patients with HER-2 negative clinical stage II-IIIc breast cancer," Breast Cancer Research and Treatment, vol. 132, no. 1, pp. 215-223, 2012.

[184] C. A. Belfi, S. Chatterjee, D. M. Gosky, S. J. Berger, and N. A. Berger, "Increased sensitivity of human colon cancer cells to DNA cross-linking agents after GRP78 up-regulation," Biochemical and Biophysical Research Communications, vol. 257, no. 2, pp. 361-368, 1999.

[185] R. Pieters, S. P. Hunger, J. Boos et al., "L-asparaginase treatment in acute lymphoblastic leukemia," Cancer, vol. 117, no. 2, pp. 238249, 2011.

[186] A. Le, A. N. Lane, M. Hamaker et al., "Glucose-independent glutamine metabolism via TCA cycling for proliferation and survival in B cells," Cell Metabolism, vol. 15, no. 1, pp. 110-121, 2012.

[187] C. Marzano, V. Gandin, A. Folda, G. Scutari, A. Bindoli, and M. P. Rigobello, "Inhibition of thioredoxin reductase by auranofin 
induces apoptosis in cisplatin-resistant human ovarian cancer cells," Free Radical Biology and Medicine, vol. 42, no. 6, pp. 872881, 2007.

[188] M. L. Guzman, R. M. Rossi, L. Karnischky et al., "The sesquiterpene lactone parthenolide induces apoptosis of human acute myelogenous leukemia stem and progenitor cells," Blood, vol. 105, no. 11, pp. 4163-4169, 2005.

[189] S. H. Kaufmann and W. C. Earnshaw, "Induction of apoptosis by cancer chemotherapy," Experimental Cell Research, vol. 256, no. 1, pp. 42-49, 2000.

[190] K. A. Conklin, "Chemotherapy-associated oxidative stress: impact on chemotherapeutic effectiveness," Integrative Cancer Therapies, vol. 3, no. 4, pp. 294-300, 2004.

[191] G. Barrera, "Oxidative stress and lipid peroxidation products in cancer progression and therapy," ISRN Oncology, vol. 2012, Article ID 137289, 21 pages, 2012.

[192] P. A. Riley, "Free radicals in biology: oxidative stress and the effects of ionizing radiation," International Journal of Radiation Biology, vol. 65, no. 1, pp. 27-33, 1994.

[193] Y. Tateishi, E. Sasabe, E. Ueta, and T. Yamamoto, "Ionizing irradiation induces apoptotic damage of salivary gland acinar cells via NADPH oxidase 1-dependent superoxide generation," Biochemical and Biophysical Research Communications, vol.366, no. 2, pp. 301-307, 2008.

[194] T. Yamamori, H. Yasui, M. Yamazumi et al., "Ionizing radiation induces mitochondrial reactive oxygen species production accompanied by upregulation of mitochondrial electron transport chain function and mitochondrial content under control of the cell cycle checkpoint," Free Radical Biology and Medicine, vol. 53, no. 2, pp. 260-270, 2012.

[195] Y. Wang, L. Liu, S. K. Pazhanisamy, H. Li, A. Meng, and D. Zhou, "Total body irradiation causes residual bone marrow injury by induction of persistent oxidative stress in murine hematopoietic stem cells," Free Radical Biology and Medicine, vol. 48, no. 2, pp. 348-356, 2010.

[196] S. Bao, Q. Wu, R. E. McLendon et al., "Glioma stem cells promote radioresistance by preferential activation of the DNA damage response," Nature, vol. 444, no. 7120, pp. 756-760, 2006.

[197] M. Ropolo, A. Daga, F. Griffero et al., "Comparative analysis of DNA repair in stem and nonstem glioma cell cultures," Molecular Cancer Research, vol. 7, no. 3, pp. 383-392, 2009.

[198] A. M. McCord, M. Jamal, E. S. Williams, K. Camphausen, and P. J. Tofilon, " $\mathrm{CD} 133^{+}$glioblastoma stem-like cells are radiosensitive with a defective DNA damage response compared with established cell lines," Clinical Cancer Research, vol. 15, no. 16, pp. 5145-5153, 2009.

[199] S.-Y. Kim, J. G. Rhee, X. Song, E. V. Prochownik, D. R. Spitz, and Y. J. Lee, "Breast cancer stem cell-like cells are more sensitive to ionizing radiation than non-stem cells: role of ATM," PLoS ONE, vol. 7, no. 11, Article ID e50423, 2012.

[200] D.-J. Tai, W.-S. Jin, C.-S. Wu et al., "Changes in intracellular redox status influence multidrug resistance in gastric adenocarcinoma cells," Experimental and Therapeutic Medicine, vol. 4, no. 2, pp. 291-296, 2012.

[201] A. Sobhakumari, L. Love-Homan, E. V. M. Fletcher et al., "Susceptibility of human head and neck cancer cells to combined inhibition of glutathione and thioredoxin metabolism," PLOS ONE, vol. 7, no. 10, Article ID e48175, 2012.

[202] H.-W. Chiu, Y.-A. Chen, S.-Y. Ho, and Y.-J. Wang, "Arsenic trioxide enhances the radiation sensitivity of androgen-dependent and -independent human prostate cancer cells," PLoS ONE, vol. 7, no. 2, Article ID e31579, 2012.
[203] L.-C. Lin, C.-T. Yeh, C.-C. Kuo et al., "Sulforaphane potentiates the efficacy of imatinib against chronic leukemia cancer stem cells through enhanced abrogation of Wnt/ $\beta$-catenin function," Journal of Agricultural and Food Chemistry, vol. 60, no. 28, pp. 7031-7039, 2012.

[204] P. Kovacic and J. D. Jacintho, "Mechanisms of carcinogenesis: focus on oxidative stress and electron transfer," Current Medicinal Chemistry, vol. 8, no. 7, pp. 773-796, 2001.

[205] K. I. Block, A. C. Koch, M. N. Mead, P. K. Tothy, R. A. Newman, and C. Gyllenhaal, "Impact of antioxidant supplementation on chemotherapeutic toxicity: a systematic review of the evidence from randomized controlled trials," International Journal of Cancer, vol. 123, no. 6, pp. 1227-1239, 2008.

[206] W. Zhang, X.-O. Shu, H. Li et al., "Vitamin intake and liver cancer risk: a report from two cohort studies in China," Journal of the National Cancer Institute, vol. 104, no. 15, pp. 1174-1182, 2012.

[207] G. S. Omenn, G. E. Goodman, M. D. Thornquist et al., "Effects of a combination of beta carotene and vitamin A on lung cancer and cardiovascular disease," The New England Journal of Medicine, vol. 334, no. 18, pp. 1150-1155, 1996.

[208] J. Liu, X. Gu, D. Robbins et al., "Protandim, a fundamentally new antioxidant approach in chemoprevention using mouse two-stage skin carcinogenesis as a model," PLoS ONE, vol. 4, no. 4, Article ID e5284, 2009.

[209] Y. S. Kim, W. Farrar, N. H. Colburn, and J. A. Milner, "Cancer stem cells: potential target for bioactive food components," The Journal of Nutritional Biochemistry, vol. 23, no. 7, pp. 691-698, 2012. 


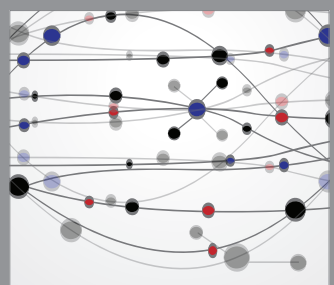

The Scientific World Journal
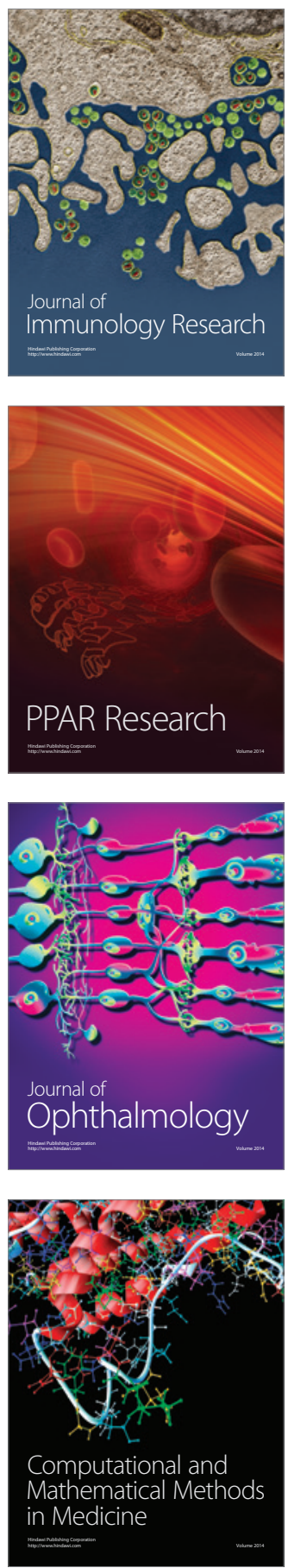

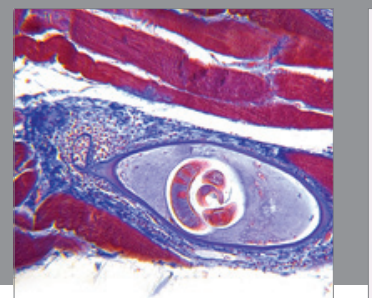

Gastroenterology

Research and Practice
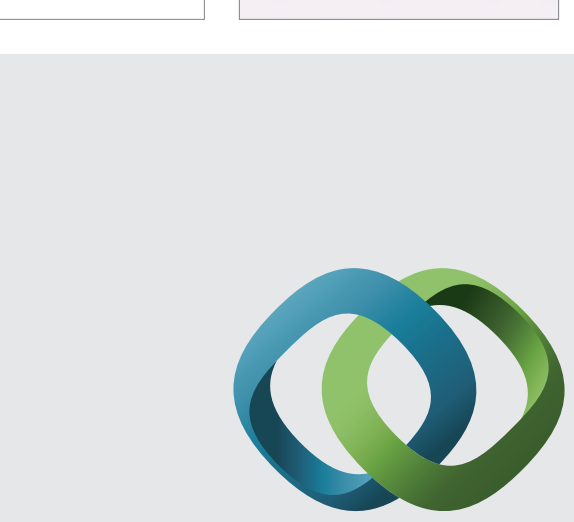

\section{Hindawi}

Submit your manuscripts at

http://www.hindawi.com
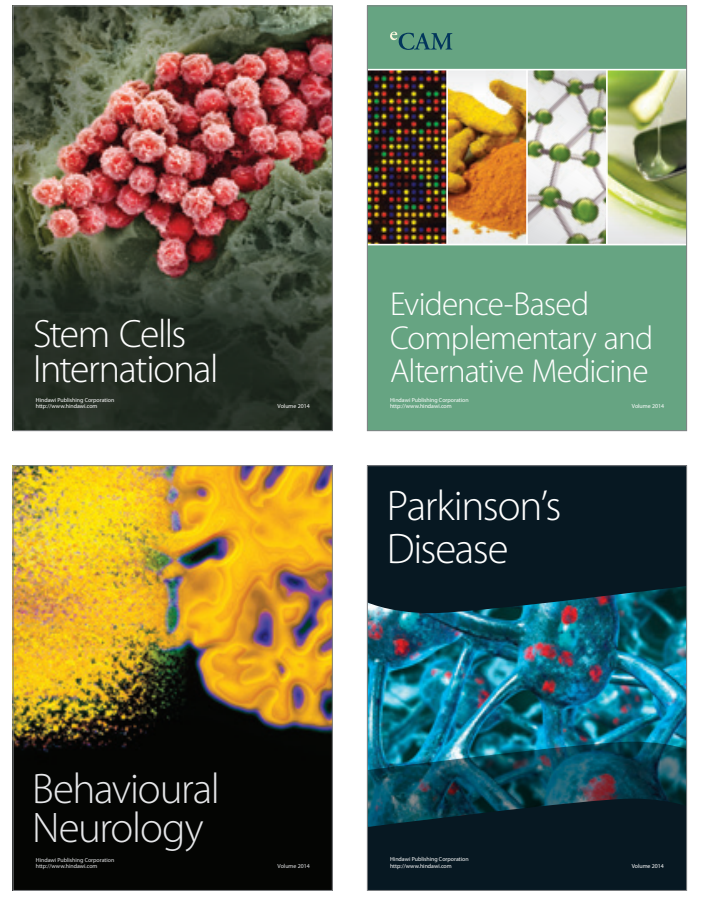
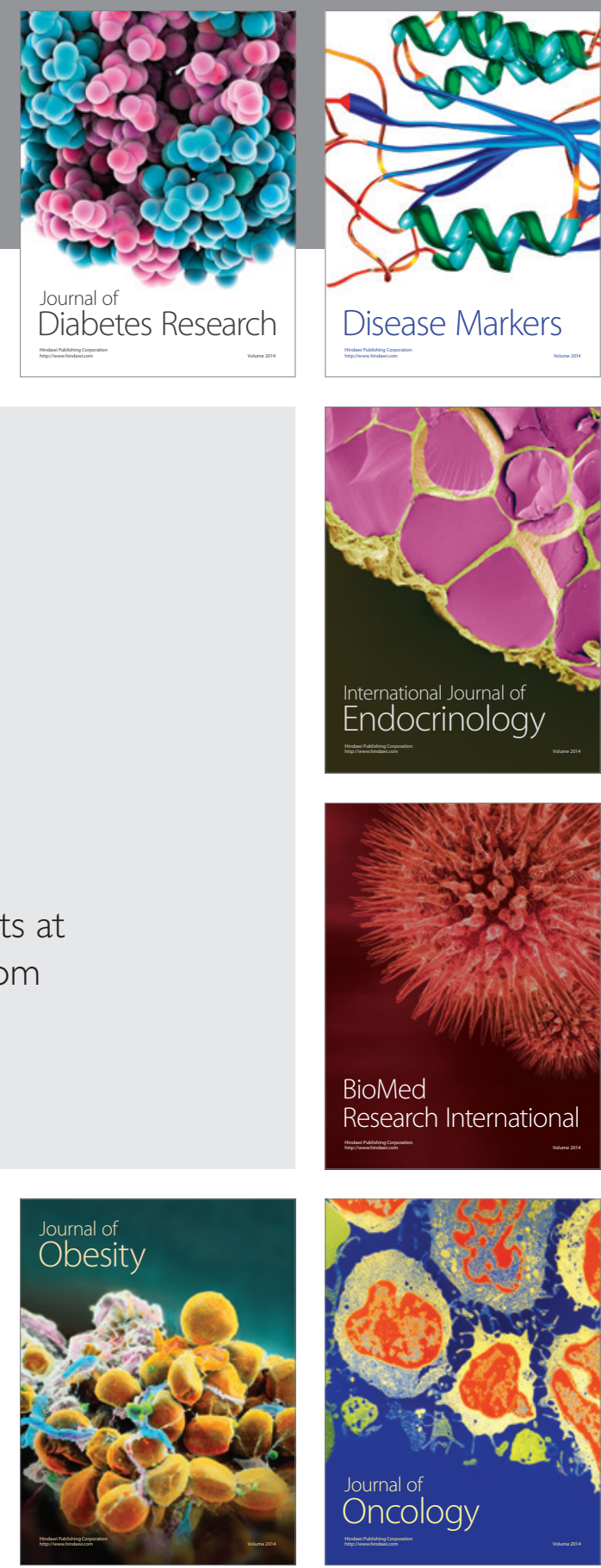

Disease Markers
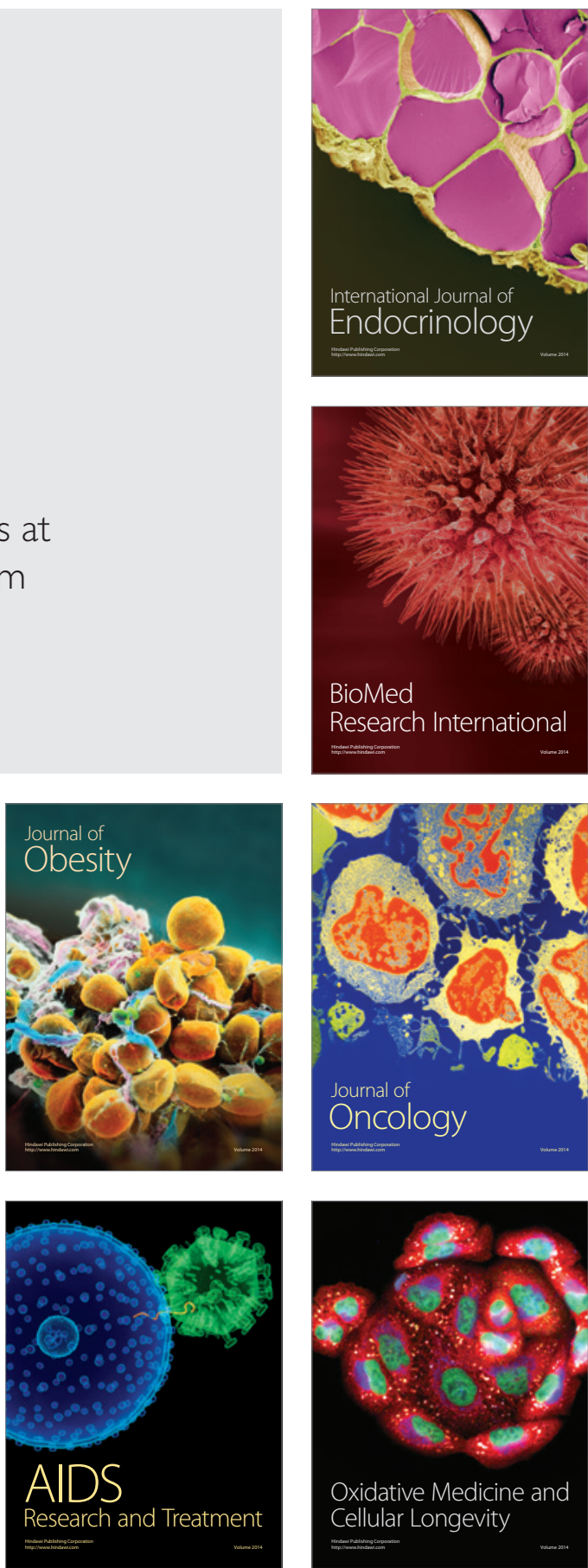